\title{
The Substance of Fritjohf Schuon's Thinking about the Point of Religions
}

\author{
Zulkarnaen \\ Ph.D Student at State Islamic University of North Sumatra (UINSU), Medan, Indonesia \\ Lecturer at State Islamic University of North Sumatra (UINSU), Medan, Indonesia
}

\begin{abstract}
:religion is not limited by what isincluded but by what is excluded by it, this lack of coverage will not destroy the deepest religious content. The substance of a human being is to believe in the existence of Lord. This is acknowledged in tauhid rububiyah of Islām people, while what distinguishes Islām from other religions is tauhiduluhiyyah. Basically, the human having religion is same. The concept of Lord in Islâm is based on revelation. The revelation here is not imagination at all as the fancy of a great poet or the artist's claim to themselves. The revelation here is not the apostolic's inspiration as claimed by biblical writers of the Bible, not the illuminative intuition of a scientist or a sharp-looking expert. The substance of FrithjofSchuont thought about the point of religions, although the external level of religion is different, but in essence all religions are the same. In other words, the unity of religions occurs at a transcendent level. Schuon'sargues that all religions have two realities or essence, namely exoteric and esoteric. The nature of exoterics is the essence of birth, which all religions have different, contradictory, contradictory dogmas, laws, rituals and beliefs.
\end{abstract}

\section{INTRODUCTION}

According to Schuon, a religion is not limited by what isincluded but by what is excluded by it, this lack of coverage will not destroy the deepest religious content. Furthermore, Schuon says that there is a mystery unknown by theologians, such as embodiment because of the lack of human metaphysical abilities in capturing the divine subjectivity. it illustrates that the divine physically cannot be captured by a theologian unless Lord Himself manifests Himselfto the chosen Prophets. According to Mahatma Gandhi in understanding about the divine by using the sample of tree and twig as follows:"In consequence, there are many truths in the traditions of religions, Hindus, Buddhists, Jews, Christians, Islām, Zoroastrians and others are true. Consequently the truth exists and is found in all religions. Religion is like a tree that has many branches but comes from one root. That one root is the origin and orientation of religions"While Sutan Akbar of India conveys his thoughts with the concept of dīn-i ilāhì (Persian:دي نالهی meaning "Lord's Religion"). Lord's Religion is a syncretic religion created by the Great emperor Mughal Akbar in 1582 AD, which combines the best elements of the religions in His empire. The elements are mostly from Islam and Hinduism, but some other elements are also taken from Christianity, Jainism and Zoroastrianism

According to IbnArabi, the point of religions is called wahdat al-adyan, etymologically is is derived from the Arabic languagewahdat which means unit, while adyan means plural religions from the word al-din. So, wahdat al adyanin essence all religions are oneaiming to Lord Almighty. the difference between religions is in the name, form and worship way, not on purpose, because the purpose is equalto Lord only, so the difference does not prevent the adherents of each religion to get at the same goal.The substance of a human being is to believe in the existence of Lord. This is acknowledged in tauhid rububiyah of Islām people, while what distinguishes Islām from other religions is tauhiduluhiyyah. Basically, the human having religion is same,ie a belief in the reality of the trasendental being of the enormous. This paradigm provides a the religious attitudes that will be owned by every believer, so in this case the researcher is interested further to discuss the thoughts of FrithjofSchuon About the Points of Religions ".

\section{METHODOLOGY}

The concept of Lord in Islâm is based on revelation. The revelation here is not imagination at all as the fancy of a great poet or the artist's claim to themselves. The revelation here is not the apostolic's inspiration as claimed by biblical writers of the Bible, not the illuminative intuition of a scientist or a sharp-looking expert.The revelation here is the word of Lordabout Himself, His creation, the relation between the two, and the path to salvation delivered to His chosen prophet and apostle, not by voice or script, but all of that, He has represented in the form of wordsdelivered By the Prophet to human beingin a form of language with his style language, yet understandable, nature without any confusion with the subjectivity and imagination of the Prophet's personal cognitive. This final revelation is believed ont only to confirm the truthfulness of the previous revelations in its 
original condition, but also to include the substance of previous books that distinguish between truth, cultural's outcomes and certain ethnic products.

Since acknowledging the Qur'an is the word of Lord revealed in the Arabic form. the description of Lord's traits in it is a description of Himself by Himself in His own words based on the Arabiclanguage. The consequence means that the Qur'ân of Arabic language, its interpretation in the hadith and the use authentically and authoritativelyall the time confirms the validity of the language to the highest degree, as the language used to describe reality and truth. The religion of revelation meantis the religions that aresent to the previous prophets before Prophet Muhammad who taught his people to always obey and serve him in all conditions, either busy or not, what the prophets teaches is The commandment of Lord that must be done by every human being on this earth.

The core, the teaching of religion teaches to always worhip and believe in daily life that Lord is exist, the one, and uncountable and human being compares in any form. Then Lord always controls human being from deed that is done. the existence of prophet Muhammad Saw in the word to assert the truth taught by previous prophet about the Great Unity.Human being never see the Lord moreover unite with Lord, the Lord concept is the teaching of holy book sent to prophet and the compheresion about the real Lord is the colour of religious tradition where human being is borned.Each of these concepts about Lord is used with different conceptual systems and frameworks, so that the conception which constitutes a wholeor super system, is not same each other. It also means that there is no unity of Lord, if what is meant by that unity is oneness (tawhid) and equality. There is plurality and religious dissimilarity, even at the transcendent level.

According to FrithjSchuon, the supernatural unity of the variousreligions can be described very clearby the interrelationship between a great religion called monotheism. The reason is that only these three religions that reveal themselves in esoteric form that cannot be reconciled with one another.If the unequal level is recognized, unity is the interconnectedness of the parts that make up the whole, then unity is the interconnection between religions, or the inequality between religions, as the parts that make up the whole.at the level of ordinary life, human beings are obidient to the limitations of humanity and the material world. Certainly there is no perfect religion, every religion are not perfect, because every religion are judged incapable of achieving its own goal, it is only able to obtain its goal of the true surrender to the great unity Lord without comparing Him with anything. In this case to understand that transcendent with Lord is based on one's faith in dealing with His form, to understand the absolute reality of the divine religion.

Every religion believes in a godly realitywhich is outside of the perishable world, but no religion states that the world in its most basic existence is utterly unreal and even 'illusion' in Hinduism is not a mere illusionthat obscures the absolute reality. If the world and the soul are not realat all, all efforts to bring the soul closer to the Absolute will be in vain. That is why that doctrine is a firm distinction between the absolute and the relative, between the degrees of reality and level ofuniversal form, and method is a way of bringing the relative reality to an absolute realitywhen it has been realized that the soul and the world that surround it are not absolute facts, that the soul of the world gains the vitality of a reality that superintend both at once.In this case, it is impossible that Allah will introduce Himself to human as his creation by using the intellectual approach had by human beings, because mind has a limitation in seeing something, moreover something is divine in seeing Lord's substance itself whereas the previous prophets can not see Lordalthough they are the chosen human to spread his teachings to every people, so that human will do his deed basedon the given instructions.

In this case Schuon sees that the most fundamental difference among Islam, Christianity and Judaism is the most substantial difference in understanding Lord as the source of all sources, and theycan not be united. this difference is only in the external aspect. whereas in its inner aspect, There is a deep conviction from various religions to believe in the existence of supernatural powers within him that can provide deep experience in the world and the hereafter namely the belief in the existence of Lord as the creator of this universe with all of the contents.If the unity of Lord is related to ontological conditions, it is not prevalent. Intended Lord is not Lord in the meaning of religion. it is impossible that the unity of Lord will occur in that condition. If Lord is known as the creator, in Islamthe actual Lord is Allah.The consequences, human being must confess and dedicate himself to Him life time until the end of the time, and not deny the His unity of both traits and forms. If the unity of Lord is related to the psychological condition, which is related to the consciousness and experience of the human personality outside of themselves, the unity of Lord perceived at that level is not at the level of religion, so only few humans can feel unity with Lord with their personality experience, and impossible humans with these psychological conditions feel the unity of Lord.

The main point, all the religions that exist will bring its own way how will occur the unity of Lord, so what is felt by human beings when there transcenden with Lordis a condition of his personality as a human beingwho can complete the divine form in understanding his oneness. it does not mean that Lord is united with the human self. Generally, every religion will be able understand the form of Lord through His creation. When we open the pages of the Qur'an, there is hardly any verse that tells of Lord. Shaykh Abdul Halim Mahmud, in his book al-islamwa al-aql, asserts that: "not only Qur'an, but also the Torah and the Gospel in its present form 
of the Old Testament And the New Testament does not describe the nature of Lord, it is because His nature is so clear and can be felt so it does not need to be explained.

The Qur'an implies that the presence of Lord is in every human being, and it has been the nature of human being since the event, see the word of Lord in Ar-Rum / 30: 30 as follows:

"Then face your face straight to the religion of Allah; (Above) the nature of Allah Who created man according to his nature. There is no change in the nature of God. (That is) a righteous religion; But most humans do not know."

See the Word of Lord in Qur'an and verse al-A'raf / 7: 172.

And (remember), when your Lord took the offspring of the sons of Adam from their sobbi and God took witness of their souls (saying): "Am I not This your Lord?" They replied: "True (You are our Tuban), we are witnesses". (We do so) so that on the Day of Resurrection you will not say: "We (the People of Adam) are the guilty of This (the unity of God)."

God can be considered as transcendent and immanent.It shows that Lord is unrivaled, and there impossible opponent that can resist the power, greatness and the creation of this beautiful universe. If He is limited in movement, he is not Lord understood in religion view because in religion Lord has no limitation and movement. He is free to do everything without any obstacle and human being in doing something has limitation and requirement. If God can unite with his beloved because the man has already surpassed what exist in his own and is considered to have extraordinary things, because he meets the nature of Lord. However, human being is a creature of Lord that has weakness and deficiency like other creatures, but human being has good traits that can unite with Lord, if the bad traits of him is removed. Actually thenoblest creature among Lord's creatures is human.FrithjofSchuon says, there are some people who can feel so close to Lord, so there is no longer the distance between human and Lord.One of them is the Sufi.Human being will not be able to understand all, because there are limits and movements of humanthat can not reach the divine. Although God encompasses all, human can not understand this concept and there is always barrier between the person and the essence of true divine.In this case, the inner experience with the reality concept will depend on the contingency of human existence. In this case it must be seen how the manifestation of Lord is present in the world. All Prophets have explained in detail how Lord will show himself from his creation, and the end huma will close with Lord through his chosen people.Schuon believes that there is an absolute reality, transcendent and it can not be achieved through the five senses. It is behind space and time. However, it can be known with pure intellectwhich can make him presenting in human. It is absolutewhich actualizes the dimension of the state in order to be aware of the mystery of its transmission.

The above comprehension indicates that Lord wants to be known not only in himself, but also from outside of himself'; starting from 'the other of Him'. It is the basic substance of Lord's. Thus, the intellectual man is someone who is able to attain essence and totality in the substance found something related to sophia perennis, it is absolute reality as the greatest worthness. The doctrine of Sophiaon the one side concerning the "heavenly Principles", on the other sidethat concerns the universal manifestation, isLord, the world and the soul. When distinguishing the embodiment between the great universe (macro cosmos) and the small universe (micro cosmos). it imples that Lord in Him has levels and forms. Lord wants to limit Himself to the image of His manifestation.

\section{DISCUSSION}

FrithjofSchuon provides a view of the unity of religions within the transcendent region. According to him, the core of religions there is a unity. The unity is not only moral but theological but also metaphysical, because it is supernatural, no one is able to explain it in the same explanation. only few people can understand it congruently. For some people who are able to understand it, the relationship between religions is not a complicated case. The existence of eternal and universal unity on the esoteric dimensions of religions, This esoteric dimensionconceptually has different of the exoteric dimension. The esoteric dimension is the spiritual dimension of the soul while the exoteric dimension is the birth of religionsritually, or other secondary branches of religions. This view will implicate for the understanding of the validity of religious pluralism.Their opinion supporting the theory of transcendent unity of religions is based on the assumption that all the major religions adhered to by human being are the religion of revelation. They assumed that universal and trancendent of exoteric correct their theory found after they know Islâmic metaphysics. They assume that their understanding of the metaphysics of the transcendent is unity of existence that contains the implications of transcendent unity of religions. There is a fatal mistake in all of their assumptions. Their claim of belief in the transcendent unity of religions is the result of their inductive imagination and is based solely on intellectual speculation, not from concrete experience.According to Schuon, the religions contain esoteric aspect (inner aspect) and exoteric (aspect of birth). ifhaving into the realm will feel the difference, then there is dividing line vertically and horizontally separating between the religion with other religions. It will eventually lead to the unity of supernatural through the intersection of those religions.as Schuon's expression follows: 
"Schuon draws the line between esoteric and exoteric. And immediately we begin to suspect that we are in the presence of something different. The fundamental distinction is not between religions. It not, so to speak a line that reappearing divides religion's great historical manifestations vertically. Hindus from Budhhists from Christians from Muslim and so on. The dividing line is horizontal and happening but cutting across the historical religion's. Above the line liesesoterism, below it exoterism. (Schuongets the dividing line between esoteric and exoteric, and will feeldifference atmosphere.The basic difference is not between one religion and another religion. this line is not dividing the great historical embodiment of religions Vertically such asHinduism, Buddhism, Christianity, Islam and so on.On the contrary, the dividing line is horizontal and drawn only once to across the various religions encountered throughout history.On the line, there is esoteric understanding, whereas under it, there is an exoteric understanding."

See Schuon's view above about dividing line of the vertical and horizontal that separates between the onereligions and another religion. Generally, humans will not be able to grasp Schuon's thinking if they do not examine the nature of common intersection of religions deeply.

As Schuon's expression follows:

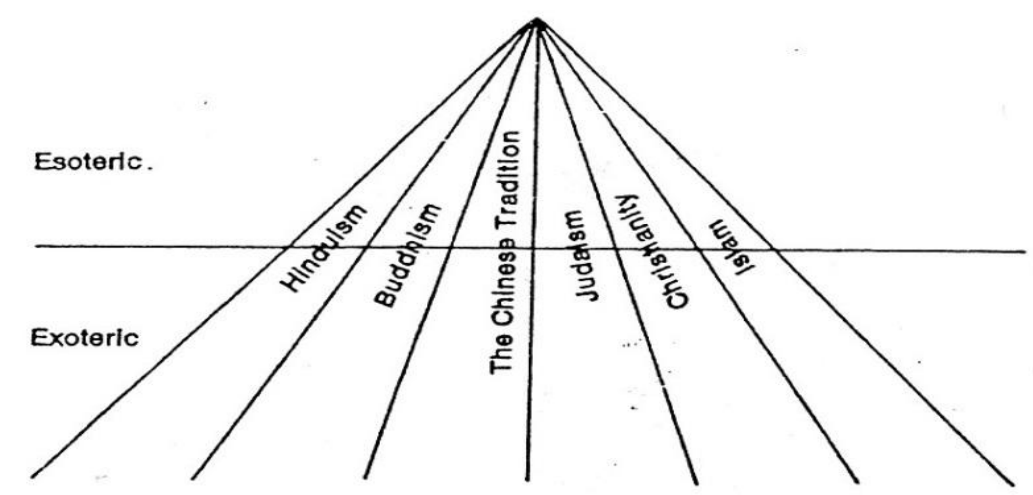

"It could be objected that this horizontal line is not as original as it might appear, the thesis that religions are alike at heart or in essence (read esoterically) while differing in form (exoterically) has often been advanced. The point is well taken. we do not arrive at Schuon orininality untilwe ask into the nature of religion's essence or (in the title of this book) transcendent unity."

"(It may be argued that this horizontal line is not as original as thought, since the views of religion basically or essentially(read esoterically) are same and different in the form (exoterically)has often been proposed. This view is appropriate. In this case we will not grasp the originality of Schuon's opinion if we do not discuss the general nature of religion or the supernatural unity itself."

Schuon in conctructing his mindis about the point of religions. The first thing is "vertical" and disconnected, while the second is "horizontal" and continuous. Both show the existence of meetings and fusion. Both of these meet and unite in metaphysical revelation.Schuon believes that essential truth ison the 'core' of every physical being. This is what Schuon calls 'the absolute truth' coming from the perspective of religious perennis. From this there is a concept of unity of religions in the transcendent region.In essence, the religions in the world coming from a single source and a universal truthare the supernatural. Only the designations for these supernatural beings can differ basedon their being from metaphysical knowledge. Especially for the expression of the embodiments of various religions becomes a separate case. What is the most appropriate way, so that among the religions are found harmony and not a difference that needs to be debated. It is intended of the transcendent unity of religions with the term 'unity' are not the parts that make up a coherent totality, but the 'totality' itself, so the 'unity' does not mean 'common religion'. However, the bearers of the concept of transcendent unity of religions have discussedabout the concept of Lord at the level of transcendence where each religion is considered valid in its limited form and conveys the same truth in a limited way. This opinion is also not true, each religion has the concept of Lord that is exclusive or different each other.

The most fundamental part of human being is intelligence, will and feeling, that the last must be understood in the deepest term. it can besaid from a certain point of view, knowledge, fear and love, also the essence of violence and tenderness. By understanding the use of intelligence that exist of human unitycan not be understood simply by saying that human is diverse, composed of various tribes and religions, which just describes the impression of fragmentation. The unity of humanity that exists in human themselves will be found absolute reality and Supreme Being. The reality logically can not achieve it as a posteriori through his will and creation.According to Schuon, humans are fighting for life. The transcendent truth and the divine reality reflect in words are so limited and relative. Schuon offers an alternative way to heal the wounds of a certecyanistic, modern man by inviting them to see the truth through intellectual intuition through the eyes of the heart beyond 
the rationalism and sense of imprealism. Human in Islam is as equal as in other monotheistic religion, that is composed of two elements, physical and spiritual elements. The human body comes from matter and has the immaterial desires of evil, whereas the soul comes from a sacred element inviting to purity. if one is only concerned with the purity It is easily drifted by an unclean life, even it can be carried away to evil.

It has been mentioned that there are a group of Islam's people who have not been satisfied with their approach to Lord through worship. They want to feel closer to Lord. Philosophy is a part of human civilization. All civilizations that ever arise in this worldmust have their own philosophy. This fact at the same time denies that thatphilosophize is only Westerners, especially the Greeks. In Schuon's view, the nature of human existence is between two dimensions, namely the dimensions of theology and the dimension of deity. Schuon argues that modern thought, both philosophy and sciencehas acknowledged the dimensions of luxury human and ignores the divine dimension. Schuon explains how the urgency of the intellect as the only form of qualification of a man's morality when united with God. Thus, it can be concluded that the 'portion' of the intellect must be proportional to the moral portion. Unless, consequence isspiritually that will be obtained intellect that is not work. The intellectual and spiritual relationships are described as the relationship between the center and the periphery. Intellectuality becomes a spiritualwhen man fully lives in truth.

In another term, metaphysical knowledge is "the source of the truth" and "the source of natural origin," whereas theological knowledge is the "embodiment" of the supernatural and can only be understood in the "dogmatic" language, thus the various religions are The "translation" of metaphysical truths or universal truths with dogmatic language.Therefore, although the intrinsic truths of dogma can not be understood by everyone, including through the intellect, but can only be understood through the belief. This is the only possible way for humans to participate in the 'divine truth'.

According to Schuon, either a fallen or surpassed human is a kind of incomplete human. The purity of man does not prevent him for having logic. That way man will find his true home. Somethingthat is needed will drive man to be the self. To the center of the self with the revelation of Lord, with the sacredness of the world will take human to the realization of goodness, beauty and love that overflows in creation.

Apart from all the deficiencies having it must be admitted that human beings are the best creations of Allah, who have the nature and instinct of humanity to always tend to the truth of Islam's function, this case is the perfect to provide guidance to humans in order to actualize positive potential and diminish its negative potential.

According to FrithjofSchuon,human is between heaven and world, or between the principle of deity and universal manifestation.He is destined to live in two dimensions, on the one side he has the right existentially to experience the nature without the worldly conditions.humanity will not have Positive content. On the other side, his spiritual duty is to leave the excessive worldly. If it fails in this task, its relationship with the heavenly dimension will be lost, as a consequence of lost its salvation. In other words, humans must always maintain horizontal and vertical relations simultaneously.

\section{CONCLUSION}

The substance of FrithjofSchuont thought about the point of religions, although the external level of religion is different, but in essence all religions are the same. In other words, the unity of religions occurs at a transcendent level. Schuon'sargues that all religions have two realities or essence, namely exoteric and esoteric. The nature of exoterics is the essence of birth, which all religions have different, contradictory, contradictory dogmas, laws, rituals and beliefs. While the essence of esoteric is the essence of the mind which all religions is with all the differences and contradictions.

The basic of logical and theoretical of Schuondia's thought calls that his theory is 'transcendent unity of religions'. In the view of Schuon, all religions are separated not by a vertical line, but a horizontal line that divides all religions. The line does not separate religion from one religion to another, but separates between the lower (exoteric) level of all religions with the upper (esoteric) level.

According to Schuon, the absolute in all religions is the esoteric dimension, while the exoteric dimension is relative to relate to other religions. All the different religions in the exotericcan meet at one point, the esoteric or divine regions. All the religions that have existed on this earth are nothing more than an incarnation of the reality of a single principle, even though all religions become extinct and vanish, but the reality of a single principle or reality of origin that exists essentially-substantially in all religions will always persist. The unity of religions occurs in the divine heavens or the esoteric areas of religions. The harmonization and contribution of his thinking, want to understand more about perenialphilosophy, which can bring the main religious awareness on the unity of religious messages wrapped in vessel of religions. If indeed there is a difference of thought and view about the reality of origin or a single principle, it really is nothing more than a factor of exclusivism in religion. 


\section{REFERENCES}

[1]. Aceng Abdul Azisdkk, IslâmAhlussunnahWalJamaah: SejarahPemikirandanDinamika NU di Indonesia, Jakarta: LP Ma'arif NU, CetII, 2015.

[2]. AdninArmas,Pluralisme Agama: TelaahKritisCebdikiawanMuslim, Jakarta: Insists, Cet I, 2013.

[3]. AlwiShihab,MembendungArus:ResponGerakanMuhammadiyahTerhadapPenetrasiMisi Kristen di Indonesia,Bandung:Mizan, cet I, 1998.

[4]. AnwarsyahNur, Din i-IlahiPemikiranSinkretisKeagamaan Sultan Akbar The Great (1656-1605), Bandung: Citapustaka Media, cet I,2014.

[5]. BudhyMunawarRachman, IslâmPluralis, WacanaKesetaraanKaumBeriman, Paramadina, Jakarta, 2001.

[6]. Frithjof Schuon, Islam and the Perennial Philosophy, London: Word of Islam Festival Publishing, 1976.

[7]. Frithjof Schuon, The transcendent Unity of Religions. Wheston, Illinois: The Theosophical Publishing House, 1984.

[8]. Frithjof Schuon, Life and Teachings, ed, New York: State University Of New York Press, 2004.

[9]. FrithjofSchuon, The Transfiguration of Man, United States of Amerika:Word Wisdom Books, 1995.

[10]. Frithjof Schuon, Art From The Sacred to the Profane: East and West, Worlds Wisdom 2007.

[11]. HasanHanafi, Islām in the World:Religion, Ideology and Development Bagian I,Mesir: Dar Keba Bookshop, 1995.

[12]. HarunNasution,Islâm di TinjaudariBerbagaiAspeknya, Jakarta: UI Jilid I cet IV, 1985.

[13]. HarunNasution, Islâm di TinjaudariBerbagaiAspeknya, Jakarta: UI Jilid II cet II 1985.

[14]. IbnArabi, Futuhatal-Makkiyah, vol I,Kairo: al-Maktab al-Arabiyah, 1979.

[15]. Jhon L. Esposito, Ensiklopedi Oxford Dunia Islam Modern, Bandung: Mizan, 1995.

[16]. KautsarAzhariNoer, Ibn al- 'Arabiwahdat al-wujuddalamPerdebatan, Jakarta: Paramadina, 1995.

[17]. NurcholisMadjid,IslâmDoktrindanPeradaban: SebuahTelaahKritistentangMasalahKeimanan, KemanusiaandanKemodernan, Jakarta: Paramadina, 2000, hlm. 180.

[18]. Muhammad Iqbal,IbnRusyddanAveroisme: PemberontakanTerhadap Agama, Bandung: Media PerintisCet II, 2011.

[19]. MurtadhaMuthahari, KeadilanIlahi: AsasPandanganDunialslâm. Penerjemah. AgusEfendi, Bandung: Mizan, 1997.

[20]. Stephen Hirtenstein,Unlimited Mercifier : The Spritual Life and Thought of Ibn 'Arabi, terjemahan "Dari KeragamankeKesatuanWujud: AjarandanKehidupanSpritualSyaikh al- Akbar Ibn 'Arabi, Jakarta:RajagrafindoPersada, cet I, 2001.

[21]. William C. Chittick, The Sufi Path of Knowledge,terjemahan Pengetahuan Spiritual, AchmadNiddjam, M. Sadat Ismail, danRuslani, Yogyakarta: Qalam, 2001.

[22]. Umar AsasuddinSokah, Din-I-Ilahi: KontroversiKeberagamaan Sultan Akbar Agung, Jogjakarta: Itaqa Press, 1994.

[23]. Yunasril Ali,SufismedanPluralisme:MemahamiHakikat Agama danRelasaiAgamaagama,Jakarta:Gramedia, cet I, 2013.

[24]. Ugi Suharto,PemikiranIslām Liberal:PembahasanIsu-isuSentral,Selanggor:DewanPustakaFajar, cet I 2007. 